\title{
\begin{tabular}{l|l|l} 
& Jurnal Kependidikan Dasar & Volume :3 \\
& Nomor : 2 \\
\hline Islam Berbasis Sains & Tahun : 2018 \\
\hline
\end{tabular}
}

\section{Penerapan Model PBL dan GI Terhadap Kemampuan Menganalisis Fenomena Sosial Berorientasi Pendekatan Interdisipliner}

\author{
Ilmawati Fahmi Imron, dan Kukuh Andri Aka \\ PGSD UNP Kediri \\ Surel : ilmawati@unpkediri.ac.id,dan kukuh.andri@unpkediri.ac.id
}

\begin{abstract}
This study aims to describe the ability to analyze social phenomena oriented in the interdisciplinary approach of social studies learning, and to describe the differences in the ability to analyze social phenomena oriented in interdisciplinary approach of social studies learning by applying PBL and GI model to PGSD students of UN PGRI Kediri.

This research type is experimental with Nonequivalent Groups Design research design that is done by comparison of model treatment applied by group $A$ and group $B$ model to know the ability of analyzing social phenomena of social studies learning in PGSD student UN PGRI Kediri. Group A uses the PBL (Problem Based Learning) model and group B uses GI (Group Investigation). Research subjects are students of UN PGRI Kediri. Technique used in this research is giving test. Instruments used to collect data in this study is a scoring sheet or test sheet in the form of a description of the problem that refers to an indicator of the ability to analyze social phenomena oriented interdisciplinary approach.

The analytical technique used in this study uses inferential statistics. The results of this study indicate that there are differences in the ability to analyze social phenomena in the class of PBL and GI shown $t$ count 6.069 with significance $0.000<0.050$. From these differences the PBL model is determined to be superior to the GI model, based on the comparison of posttest and pretest values. The difference of the PBL model is 16.08 points, while the GI model is 6.56 points.
\end{abstract}

Keywords: PBL, GI, social phenomena, Fenomena sosial, interdisciplinary approach

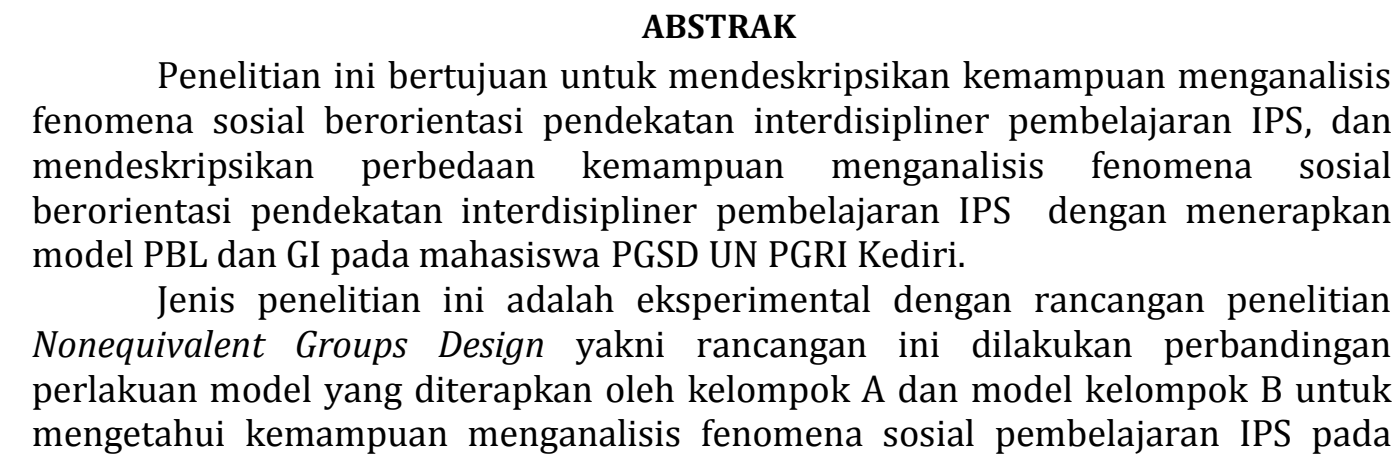


mahasiswa PGSD UN PGRI Kediri. Kelompok A menggunakan model PBL (Problem Based Learning) dan kelompok B menggunakan GI (Group Investigation). Subjek penelitian adalah mahasiswa UN PGRI Kediri. Teknik yang digunakan dalam penelitian ini adalah pemberian tes. Instrumen yang digunakan untuk mengumpulkan data dalam penelitian ini adalah lembar penilaian atau lembar tes tulis berbentuk soal uraian yang mengacu pada indikator kemampuan menganalisis fenomena sosial berorientasi pendekatan interdisipliner.

Teknik analisis yang digunakan dalam penelitian ini menggunakan statistik inferensial. Hasil pada penelitian ini menunjukkan bahwa ada perbedaan kemampuan menganalisis fenomena sosial pada kelas PBL dan GI ditunjukkan t hitung 6,069 dengan signifikansinya $0,000<0,050$. Dari perbedaan tersebut model PBL ditentukan lebih unggul dibandingkan dengan model GI, berdasarkan perbandingan nilai posttest dan pretest. Selisih model PBL yakni 16,08 point, sedangkan model GI yakni 6,56 point.

Kata kunci: Model PBL, Model GI, Fenomena sosial, Pendekatan interdisipliner, IPS 


\section{A. PENDAHULUAN}

Dalam undang-undang pendidikan tinggi No.12 tahun 2012, perguruan tinggi merupakan pendidikan tinggi yang bertujuan untuk mencerdaskan Bangsa dengan mengembangkan kemampuan dan membentuk watak serta kepribadian Bangsa yang bermartabat. ${ }^{1}$ Berdasarkan tujuan tersebut, perguruan tinggi seharusnya mampu memfasilitasi penggunanya dalam memberikan pengalaman belajar yang sesuai dengan tuntutan masyarakat. Tuntunan tersebut salah satunya mahasiswa harus mampu menjadi Agent of Change atau agen perubahan. Mahasiswa dilatih dan dididik di perguruan tinggi, sehingga diharapkan mereka kembali ke masyarakat mereka melakukan perubahan yang positif di masyarakat.

Pengalaman belajar yang mampu mengembangkan kemampuan watak dan kepribadian mahasiswa salah satunya pembelajaran IPS. Pembelajaran IPS merupakan pembelajaran interdisipliner dari berbagai ilmu sosial yakni sejarah, geografi, sosiologi, antropologi, psikologi sosial, dan hukum. Pembelajaran IPS merupakan pembelajaran yang mengambil topik masalahnya dari kehidupan sehari-hari. Pembelajarannya tidak hanya secara teori namun diselesaikan secara praktik sehingga pembelajaran IPS diharapkan dapat meningkatkan kepekaan mahasiswa

\footnotetext{
${ }^{1}$ Kopertis, "Modul Pelatihan Pengembangan Keterampilan Dasar Teknik Instruksional (Pekerti)" (Kopertis Wilayah 7, 2014).
}

dalam menanggapi suatu permasalahan di masyarakat. ${ }^{2}$

Kajian pembelajaran IPS yang dapat meningkatkan kepekaan mahasiswa dalam menanggapi suatu permasalahan di masyarakat salah satunya fenomena sosial. Fenomena sosial merupakan kajian pembelajaran IPS yang terdiri atas berbagai perilaku dan gejala-gejala sosial di masyarakat. Fenomena sosial atau permasalahan sosial merujuk kepada suatu kondisi yang tidak diinginkan, tidak adil, berbahaya, ofensif, dan dalam pengertian tertentu mengancam kehidupan masyarakat. ${ }^{3}$ Fenomena sosial yang dijadikan sebagai bahan kajian IPS adalah gejala-gejala sosial yang menyimpang dari nilai-nilai sosial yang dapat menimbulkan permasalahan baik pada individu itu sendiri maupun pada kelompok sosial yang lainnya.

Pada penelitian ini peneliti menggunakan fenomena sosial sebagai konsep dari ilmu sosial, yang selanjutnya penyelesaiannya akan dibahas dari beberapa sudut pandang ilmu yang serumpun dengan ilmu sosial yang lain (Interdisipliner). ${ }^{4}$ Misal fenomena sosial (yang digunakan adalah kemiskinan, narkoba, anak jalanan, dan prostitusi) akan dicari penyebab, dampak,

\footnotetext{
2 Iif Khoiru Ahmadi and Sofan Amri, Mengembangkan Pembelajaran IPS Terpadu (Jakarta: PT. Prestasi Putrakaraya, 2011).

${ }^{3}$ H. Dadang Supardan, Hamid Hasan, and Rini Rachmatika, Pengantar Ilmu Sosial: Sebuah Kajian Pendekatan Struktural (Jakarta: Bumi Aksara, 2008).

4 "Materi Pengayaan Pendidikan IPS PGSD/MI," $M r$ SANYATA JAKA SANTOSO (blog), October 29, 2010, https://mrcumlaude.wordpress.com/2010/10/2 9/materi-pengayaan-pendidikan-ips-pgsdmi/.
} 
dampak lanjutan, dan solusi penyelesaiannya dari ilmu sosiologi, geografi, antropologi, ekonomi, hukum, politik, dan psikologi sosial, sehingga dalam satu permasalahan akan dibahas ke dalam beberapa disiplin ilmu yang serumpun.

Berdasarkan hal tersebut, maka peneliti melakukan observasi pada kelas 1C PGSD UN PGRI Kediri yang menerapkan pembelajaran IPS guna mengetahui sejauh mana mahasiswa mampu menganalisis fenomena sosial yang ada disekitarnya. Berdasarkan hasil observasi didapatkan hasil bahwa banyak mahasiswa yang kurang tanggap terhadap permasalahan yang ada di masyarakat. Hal ini terbukti saat mahasiswa diberikan kuis tanya jawab tentang materi fenomena sosial, mereka banyak yang menjawab dengan ragu-ragu dan jawabannya kurang tepat.

Mencermati kendala tersebut, maka peneliti mengindikasi kemampuan menganalisis fenomena sosial mahasiswa tingkat 1 semester 2 rendah, karena menerapkan model yang kurang sesuai dengan bahan kajian fenomena sosial. Banyak mahasiswa merasa kesulitan dalam mengidentifikasi suatu masalah, kesulitan dalam menyimpulkan dampak dan dampak lanjutan, serta kurang mampu menyajikan berbagai solusi dari berbagai fenomena sosial.

Berdasarkan indikasi tersebut, maka peneliti bermaksud melakukan perbandingan dua kelas ekseprimen dengan membandingan model pembelajaran yang berbeda agar mengetahui model pembelajaran mana yang paling efektif diterapkan dengan bahan kajian fenomena sosial. Model pembelajaran yang digunakan pada kelas eksperimen tersebut adalah model Problem Based Learning (PBL) dan Group Investigation (GI).

Kedua model di atas dipilih karena model pembelajaran tersebut menghadapkan pebelajar pada masalah nyata yakni fenomena sosial, pebelajar aktif bekerjasama di dalam kelompok untuk mencari solusinya. Kedua model ini menuntut pebelajar untuk meningkatkan kemampuan berpikir tingkat tinggi.

Adapun perbedaan kedua model tersebut terletak pada sintaksnya, yakni model Problem Based Learning dengan sintaks (1) mengorganisasikan mahasiswa kepada masalah, (2) mengorganisasikan mahasiswa untuk belajar (3) membantu penyelidikan mandiri dan kelompok, mengembangkan dan menyajikan hasil karya serta memamerkannya, dan (5) menganalisis dan mengevaluasi proses pemecahan masalah. ${ }^{56}$ Kemudian untuk sintaks model Group Investigation (GI) yakni (1) mengorganisasikan mahasiswa ke dalam beberapa kelompok, (2) dosen membagi tugas tiap kelompok dengan permasalahan yang berbeda, (3) masingmasing kelompok membahas materi yang sudah ada secara kooperatif, (4) mahasiswa menyampaikan hasil diskusi,

\footnotetext{
${ }^{5}$ Mohamad Nur, Model Pembelajaran Berdasarkan Masalah (Surabaya: Pusat Sains dan Matematika Sekolah Unesa, 2011).

${ }^{6}$ Sugiarso and Mustaji, Pembelajaran Berbasis Konstruktivistik (Penerapan Dalam Pembelajaran Berbasis Masalah) (Surabaya: Universitas Negeri Surabaya, 2005).
} 
(5) dosen dan mahasiswa memberikan kesimpulan. ${ }^{7}$

Berdasarkan hasil penelitian sebelumnya baik model PBL dan GI juga terbukti memiliki pengaruh yang signifikan antar satu sama lainnya dalam meningkatkan hasil belajar pebelajar pada materi IPS, seperti penelitian Pranoto ${ }^{8}$ yang membuktikan bahwa PBL lebih unggul dan penelitian Octaviani (2013) yang membutikan GI lebih unggul.

Dari uraian di atas, melalui judul "Penerapan Model PBL dan GI terhadap Kemampuan Menganalisis Fenomena Sosial Berorientasi Pendekatan
Interdisipliner", peneliti memiliki tujuan untuk mengetahui ada tidaknya perbedaan kemampuan menganalisis fenomena sosial berorientasi pendekatan interdisipliner pembelajaran IPS dengan menerapkan model PBL dan GI pada mahasiswa PGSD UN PGRI Kediri".

\section{B. METODE}

Pada penelitian ini, jenis penelitian yang digunakan yakni eksperimen dengan teknik penelitian Nonequivalent Control Groups Design yakni membandingkan dua perlakuan yang berbeda pada dua kelas dengan materi yang sama. Perbandingan

Tabel 1. Hasil uji validitas butir soal

\begin{tabular}{|c|c|c|c|c|c|c|}
\hline \multicolumn{7}{|c|}{ Correlations } \\
\hline & & item_1 & item_2 & item_3 & item_4 & Skor_total \\
\hline \multirow{4}{*}{ item_1 } & Pearson & 1 & $.478^{*}$ & $.789^{* *}$ & .236 & $.790^{* *}$ \\
\hline & Correlation & & & & & \\
\hline & Sig. (2-tailed) & & .021 & .000 & .279 & .000 \\
\hline & $\mathrm{N}$ & 23 & 23 & 23 & 23 & 23 \\
\hline \multirow{4}{*}{ item_2 } & Pearson & $.478^{*}$ & 1 & $.492^{*}$ & $.657^{* *}$ & $.856^{* *}$ \\
\hline & Correlation & & & & & \\
\hline & Sig. (2-tailed) & .021 & & .017 & .001 & .000 \\
\hline & $\mathrm{N}$ & 23 & 23 & 23 & 23 & 23 \\
\hline \multirow{4}{*}{ item_3 } & Pearson & $.789^{* *}$ & $.492^{*}$ & 1 & .132 & $.755^{* *}$ \\
\hline & Correlation & & & & & \\
\hline & Sig. (2-tailed) & .000 & .017 & & .548 & .000 \\
\hline & $\mathrm{N}$ & 23 & 23 & 23 & 23 & 23 \\
\hline \multirow{4}{*}{ item_4 } & Pearson & .236 & $.657^{* *}$ & .132 & 1 & $.688^{* *}$ \\
\hline & Correlation & & & & & \\
\hline & Sig. (2-tailed) & .279 & .001 & .548 & & .000 \\
\hline & $\mathrm{N}$ & 23 & 23 & 23 & 23 & 23 \\
\hline \multirow{4}{*}{$\begin{array}{l}\text { Skor_tota } \\
1\end{array}$} & Pearson & $.790^{* *}$ & $.856^{* *}$ & $.755^{* *}$ & $.688^{* *}$ & 1 \\
\hline & Correlation & & & & & \\
\hline & Sig. (2-tailed) & .000 & .000 & .000 & .000 & \\
\hline & $\mathrm{N}$ & 23 & 23 & 23 & 23 & 23 \\
\hline
\end{tabular}

*. Correlation is significant at the 0.05 level (2-tailed).

**. Correlation is significant at the 0.01 level (2-tailed). 
perlakuannya menerapkan model PBL dan model GI guna mengetahui model pembelajaran mana yang paling efektif digunakan pada mata kuliah IPS materi fenomena sosial.

Subjek penelitian adalah mahasiswa UN PGRI Kediri program studi PGSD semester 2 kelas A dan kelas B yang ratarata berumur 18 tahun. Kelas yang menerapkan kelas PBL adalah kelas A berjumlah 23 mahasiswa, sedangkan kelas yang menerapkan GI adalah kelas B berjumlah 23 mahasiswa.

Instrumen yang digunakan untuk mengumpulkan data pada penelitian ini adalah (1) lembar validasi perangkat pembelajaran dan instrumen penelitian yang terdiri atas lembar validasi RPP, materi ajar, unjuk kerja mahasiswa, dan rubrik penilaian (afektif, kognitif, dan psikomotor), (2) lembar tes tulis yang tertuang dalam lembar penilaian mahasiswa. Teknik analisis datanya menggunakan uji-t dengan bantuan SPSS 23.0.

Untuk mengetahui kelayakan instrumen, maka perlu dilakukan uji coba. Uji ini meliputi uji validitas dan reliabilitas. Setelah semua instrumen disusun kemudian dilakukan validasi ahli dan dinyatakan layak, maka setelah itu untuk instrumen rubrik penilaian dilakukan uji validitas butir soal. Perhitungan validitas butir soal dilakukan dengan menggunakan uji spearmen's rho dengan bantuan SPSS 23.0.

Validitas butir soal ini diujicobakan pada mahasiswa semester 2 kelas $\mathrm{C}$ dengan jumlah responden sejumlah 23 siswa yang dipilih secara acak. Bila skor item berkorelasi secara signifikan dengan total skor pada tingkat kepercayaan 95\% $(\alpha=0,05)$ atau probabilitas $<0,05$ dan nilai $r$ hitung $>r$ tabel $(r$ tabel dengan signifikansi 0.05 dan $\mathrm{N}=23$ adalah 0,444 ) maka dapat dikatakan item pertanyaan valid.

Berikut hasil dari uji validitas butir soal dapat dicermati seperti tabel di bawah iniBerdasarkan pedoman dan data di atas, seluruh $r$ hitung berada di atas $r$ tabel, maka empat butir soal di atas dinyatakan seluruhnya valid.

Kemudian untuk reliabilitas dihitung menggunakan formula alpha dari cronbach dengan kriteria realibitas Alpha adalah sebagai berikut:

Tabel 2. Reliabilitas berdasarkan Alpha

\begin{tabular}{|l|l|}
\hline Alpha & Tingkat Reliabilitas \\
\hline $0.00-0.20$ & Kurang reliabel \\
\hline $0.20-0.40$ & Agak reliabel \\
\hline $0.40-0.60$ & Cukup reliabel \\
\hline $0.60-0.80$ & Reliabel \\
\hline $0.80-1.00$ & Sangat reliabel \\
\hline \multicolumn{2}{|c|}{ Sumber: Sugiono $(2012)$} \\
\hline
\end{tabular}

Dari hasil perhitungan SPSS muncul nilai reliabilitasnya adalah 0,767 , artinya data tersebut reliabel. Berikut hasil uji reliabilitas menggunakan SPSS 23.0.

Tabel 3. Hasil uji reliabilitas butir soal

\begin{tabular}{|c|c|}
\multicolumn{1}{c|}{ Reliability Statistics } \\
\begin{tabular}{|c|c|} 
Cronbach's \\
Alpha
\end{tabular} & $\begin{array}{c}\text { N of } \\
\text { Items }\end{array}$ \\
\hline .767 & 4 \\
\hline
\end{tabular}

Setelah instrumen dikatakan valid dan reliabel maka instrumen digunakan untuk mengumpulkan data, setelah data terkumpul, maka dilakukan analisis data. Kegiatan dalam analisis data yaitu, 
melakukan perhitungan untuk menjawab rumusan masalah, dan melakukan perhitungan untuk menguji hipotesis yang telah diajukan. ${ }^{9}$ Teknik analisis statistik yang digunakan pada penelitian ini adalah sebagai berikut.

Uji prasyarat. Adapun uji prasaratnya yaitu uji normalitas, yang bertujuan untuk mengetahui data terdistribusi normal atau tidak. Pengujian normalitas data pada penelitian ini menggunakan uji Shapiro-Wilk dibantu dengan SPSS 23.0. Setelah uji normalitas, dilakukan uji homogenitas, pengujian homogenitas sampel menjadi sangat penting apabila peneliti bermaksud melakukan generalisasi untuk hasil penelitiannya serta penelitian yang data penelitiannya diambil dari kelompokkelompok terpisah yang berasal dari satu populasi. ${ }^{10}$ Pengujian homogenitas ini dilakukan dengan menggunakan uji Levene Statistic dibantu dengan SPSS 23. 0 .

Untuk menjawab rumusan masalah dan menarik kesimpulan apakah hipotesis penelitian diterima atau tidak digunakan ketentuan sebagai berikut:

- Hipotesis nol (Ho) = tidak ada perbedaan yang signifikan antara kemampuan menganalisis fenomena sosial yang berorientasi pendekatan interdisipliner pembelajaran IPS dengan menerapkan model PBL dan GI pada mahasiswa PGSD UN PGRI Kediri

\footnotetext{
${ }^{9}$ Sugiyono, Statistika Untuk Penelitian (Bandung: Alfabeta, 2012), 147.

${ }^{10}$ Arikunto Suharsimi, Dasar-Dasar Evaluasi

Pendidikan (Jakarta: Bumi Aksara, 2002), 364.
}

- Hipotesis alternatif $(\mathrm{Ha})=$ ada perbedaan yang signifikan antara kemampuan menganalisis fenomena sosial yang berorientasi pendekatan interdisipliner pembelajaran IPS dengan menerapkan model PBL dan GI pada mahasiswa PGSD UN PGRI Kediri.

Jika signifikansi $\geq 0,05$ maka Ho diterima dan $\mathrm{Ha}$ ditolak dan jika Jika signifikansi < 0, 05 maka Ha diterima dan Ho ditolak. Pada penelitian kali ini, perhitungan uji hipotesis penelitian dilakukan dengan bantuan SPSS 23.0 dengan formula independent-sample t test.

\section{HASIL DAN PEMBAHASAN}

Data diperoleh dari kelas A sebagai kelas eksperimen I dengan menerapkan model PBL dan kelas B sebagai kelas eksperimen II dengan menerapkan model GI. Data prestasi belajar IPS pendekatan interdisipliner dengan materi fenomena sosial diperoleh dari lembar penilaian. Lembar penilaian adalah tes individu untuk mengukur kemampuan berpikir siswa dalam menganalisis suatu fenomena sosial.

Sebelum dilakukan pembahasan mengenai uji hipotesis, di bawah ini ditunjukkan hasil uji normalitas dan homogenitas data. Uji normalitas menggunakan uji Shapiro-Wilk dan uji homogenitas menggunakan uji Levene Statistic. 
Tabel 4. Hasil uji Normalitas

\begin{tabular}{|l|r|r|r|}
\hline \multirow{2}{*}{} & \multicolumn{3}{|c|}{ Shapiro-Wilk } \\
\cline { 2 - 4 } & Statistic & \multicolumn{1}{c|}{ df } & \multicolumn{1}{c|}{ Sig. } \\
\hline Kelas & .912 & 23 & .065 \\
PBL & & & \\
Kelas GI & .908 & 23 & .057 \\
\hline
\end{tabular}

Dari hasil perhitungan uji ShapiroWilk dibantu dengan SPSS, dapat dilihat pada tabel di atas nilai signifikansi kelas PBL senilai 0,065 dan kelas GI 0,057. Artinya pada kedua kelas tersebut $\geq 0,05$ maka dapat disimpulkan bahwa data yang diperoleh terdistribusi normal.

Tabel 5. Hasil uji Homogenitas

\begin{tabular}{|c|c|c|c|}
\hline $\begin{array}{c}\text { Levene } \\
\text { Statistic }\end{array}$ & $\mathrm{df1}$ & $\mathrm{df} 2$ & Sig. \\
\hline .005 & 1 & 44 & .943 \\
\hline
\end{tabular}

Dari hasil perhitungan uji Lavene Statistic dibantu dengan SPSS, dapat dilihat pada tabel di atas nilai signifikansi senilai 0,943 . Artinya nilai signifikansinya $0,943 \geq 0,05$ maka dapat disimpulkan bahwa data yang diperoleh homogen.

Setelah data dikatakan normal dan homogen, maka dilakukan uji hipotesis, perhitungan validitas dilakukan dengan bantuan SPSS 23 dengan formula independent-sample $t$ test. Berikut tabel 6 data hasil belajar kelas A dan kelas B.
Berdasarkan pada tabel 5 tertera bahwa pada pembelajaran PBL mengalami peningkatan hasil belajar yakni dari nilai 74,70 menjadi 90,78, selain itu pada pembelajaran GI juga mengalami peningkatan yakni 74,48 menjadi 81,04. Dari hasil mean tersebut ada perbedaan yang siginifikan pada model PBL dan GI yang ditunjukkan $t$ hitung 6,069 dengan signifikansinya $0,000<0,05$. Hasil rata-rata dan uji-t tersebut menunjukkan bahwa ada perbedaan antara PBL dan GI.

Setelah diketahui perbedaan antara kedua model tersebut, kemudian mencari model mana yang paling efektif digunakan. Penentuan keefektifan model pembelajaran dengan materi fenomena sosial adalah menbandingkan nilai posttest dan pretest antara model PBL dan GI. Selisih model PBL yakni 16,08 point, sedangkan model GI yakni 6,56 point. Hasil perbedaan point inilah yang dijadikan sebagai dasar menentukan keefektifan suatu model pembelajaran dengan materi fenomena sosial. Jadi pembelajaran PBL adalah model pembelajaran yang lebih efektif digunakan dalam pembelajaran IPS dengan pendekatan interdisipliner materi fenomena sosial dibanding model

Tabel 6 . Data Hasil Belajar Dengan Bantuan SPSS.

\begin{tabular}{|c|c|c|c|c|c|c|}
\hline No & Kelas & $\begin{array}{c}\text { Mean } \\
\text { Pretest }\end{array}$ & $\begin{array}{c}\text { Mean } \\
\text { Posttest }\end{array}$ & $\mathrm{t}$ & $\begin{array}{c}\text { Sig. (2- } \\
\text { tailed) }\end{array}$ & Keputusan \\
\hline 1 & PBL & 74,70 & 90.7826 & & & Meningkat \\
\hline 2 & GI & 74,48 & 81.0435 & & & Meningkat \\
\hline 3 & PBL $^{*} \mathrm{GI}$ & & & 6,069 &, 000 & Ho Ditolak \\
\hline
\end{tabular}

Keterangan: $\mathrm{PBL}^{*} \mathrm{GI}$ adalah membandingkan hasil belajar antara model PBL dan GI 
pembelajaran GI.

Pada pembelajaran menggunkan PBL mahasiswa terlihat sangat antusias dalam melaksanakan tugas melakukan observasi. Antusiasme mahasiswa dikarenakan pelaksanaan observasi dilakukan di beberapa tempat dengan topik fenomensa sosial yang berbedabeda. Pada pembelajaran dengan model GI, mahasiswa hanya menggunakan satu topik saja dalam pembelajaran, jadi observasinya hanya pada satu tempat saja.

Dibandingkan dengan GI yang hanya menggunakan satu fenomena sosial saja, model PBL lebih menggunakan masalah secara otentik, PBL juga dapat meningkatkan kemampuan berfikir kritis mahasiswa dalam menganalisis beberapa permasalahan dengan cara obsevasi, identifikasi masalah sampai menemukan solusi dari permasalahan tersebut. Dari penerapan model PBL tersebut, mahasiswa akan lebih menguasaibeberapa masalah, sehingga semakin mengasah kemampuannya dalam memecahkan permasalahanpermasalahan kehidupan sehari-hari secara komprehensif.

\section{SIMPULAN}

Berdasarkan kajian teori dan didukung oleh hasil analisis data penelitian serta mengacu pada perumusan masalah yang telah diuraikan pada bab sebelumnya maka dalam penelitian ini dapat disimpulkan sebagai berikut.

1. Terdapat perbedaan yang signifikan antara model PBL (Problem Based Learning) dan GI (Group Investigation) pada pembelajaran IPS materi fenomena sosial berorientasi pendekatan interdisispliner pada mahasiswa PGSD UN PGRI Kediri.

2. Model PBL (Problem Based Learning) merupakan model pembelajaran yang lebih efektif diterapkan pada pembelajaran IPS materi fenomena sosial berorientasi pendekatan interdisispliner pada mahasiswa PGSD UN PGRI Kediri dibandingkan model GI (Group Investigation).

\section{E. DAFTAR PUSTAKA}

Ahmadi, Iif Khoiru, and Sofan Amri. Mengembangkan Pembelajaran IPS Terpadu. Jakarta: PT. Prestasi Putrakaraya, 2011.

Aqib, Zainal. Model-Model, Media, Dan Strategi Pembelajaran Kontekstual (Inovatif). Bandung: Yrama Widya, 2013.

Kopertis. "Modul Pelatihan

Pengembangan Keterampilan Dasar Teknik Instruksional (Pekerti)." Kopertis Wilayah 7, 2014.

"Materi Pengayaan Pendidikan IPS PGSD/MI." Mr SANYATA JAKA SANTOSO (blog), October 29, 2010. https://mrcumlaude.wordpress.co m/2010/10/29/materipengayaan-pendidikan-ipspgsdmi/.

Nur, Mohamad. Model Pembelajaran Berdasarkan Masalah. Surabaya: Pusat Sains dan Matematika Sekolah Unesa, 2011.

Pranoto, Suryo. "Perbandingan Hasil Belajar Kognitif Menggunakan Model Pembelajaran Berbasis 
Masalah Dengan Model

Pembelajaran Kooperatif Tipe

Group Investigasi Mata Pelajaran

Ilmu Pengetahuan Sosial Dengan

Mempertimbangkan Bentuk Soal

Pada Peserta Didik Kelas VII

Semester Ganjil SMP Negeri 4

Blambangan Umpu Kabupaten

Way Kanan Tahun Ajaran

2014/2015," 2015.

Sugiarso, and Mustaji. Pembelajaran

Berbasis Konstruktivistik

(Penerapan Dalam Pembelajaran

Berbasis Masalah). Surabaya:

Universitas Negeri Surabaya, 2005.

Sugiyono. Statistika Untuk Penelitian.

Bandung: Alfabeta, 2012.

Suharsimi, Arikunto. Dasar-Dasar

Evaluasi Pendidikan. Jakarta: Bumi

Aksara, 2002.

Supardan, H. Dadang, Hamid Hasan, and Rini Rachmatika. Pengantar Ilmu Sosial: Sebuah Kajian Pendekatan Struktural. Jakarta: Bumi Aksara, 2008. 